\title{
Support for smallholder farmers in South Africa: Challenges of scale and strategy
}

\author{
Michael Aliber \& Ruth Hall
}

The South African Government aims to expand the smallholder sector as part of its broader job creation strategy. However, research shows that government attempts to support smallholder farmers have generally been costly and ineffective. Using secondary data and case study evidence, this study investigated the problems of supporting this sector. One finding is that while budgetary allocations to the sector have increased impressively over the last decade and a half, the distribution and use of these resources are such that few farmers benefit and the overall impact is small. A strategic choice has to be made between two strategies: supporting a few selected farmers to become large-scale commercial farmers ('accumulation for the few'), or supporting a large number and helping them to increase and diversify their produce so as to become sustainable commercial smallholders ('accumulation from below'). Past experience and a new national initiative favour the latter, using geographically targeted generic support services.

Keywords: smallholders; agricultural development; farmer support

\section{Introduction}

For much of the post-apartheid era, government has tended to make broad statements about its policy objectives for small-scale farmers. For example, the 2001 Strategic Plan for South African Agriculture, which until recently effectively served as government's primary statement on agrarian reform, posited a vision of a 'united and prosperous agricultural sector' and went on to define this vision as a 'unified sector served by a unimodal policy framework designed to bridge the inherent dualism and to maximise the contribution of the sector to economic growth and development' (NDA, 2001:3).

To the extent that there has been a particular bias in policy regarding small-scale farmers, it has been to help them to expand and commercialise. This underpins the tendency in the Strategic Plan and elsewhere to refer to smallholder black farmers as 'emerging' farmers; the implication being that they are bona fide farmers only in so far as they begin to resemble large-scale white commercial farmers, and thus will the 'inherent dualism' be healed. According to the Strategic Plan, achieving this implies ensuring 'equitable access', for want of which small-scale black farmers have been unable to compete with established commercial farmers. While the existence of subsistence and smallholder farmers is acknowledged, not least because they underscore the importance of agriculture as a sector, they are often valued only as being the nursery from which successful commercial farmers will 'emerge'.

It appears to be in reaction to the two bouts of food price inflation since 2000 that smallscale and subsistence farmers are receiving more recognition in their own right. The

Respectively, Senior Researcher, and Associate Professor, Institute for Poverty, Land and Agrarian Studies (PLAAS), School of Government, University of the Western Cape, Cape Town, South Africa. Corresponding author: maliber@uwc.ac.za 
African National Congress's resolution on 'rural development, land reform and agrarian change', adopted at its 52nd National Conference in Polokwane in 2007, highlighted the importance of household food production, and the Department of Agriculture, Forestry and Fisheries, in the foreword to its 2010/11 strategic plan, has usefully clarified its objectives by disaggregating the sector into 'subsistence', 'smallholder and 'commercial' farmers (DAFF, 2010:2). Increasingly, 'smallholders' are taking centre stage. (For the purposes of this article, the term 'small-scale farmers' includes subsistence and smallholder farmers.)

More recently, under the 'Outcomes' approach adopted by the Zuma administration, government committed itself to expanding the smallholder sector from 200000 to 250000 by 2014 (The Presidency, 2010), while under the New Growth Path compiled by the Economic Development Department, it has committed itself to expanding it to 500000 smallholders by 2020 (EDD, 2010).

How are these ambitious targets to be met?

This article reflects on the challenge of meeting these targets, meaning not just achieving the numbers, but doing so in terms of a strategy that takes seriously the desired socioeconomic benefits of a larger, more prosperous small-scale farming sector. This challenge must be seen in the context of the general failure of government attempts to reach 'the masses' through economic interventions, as a TIPS (Trade \& Industrial Policy Strategies) overview points out:

While government performance in relation to the delivery of social services such as grants and basic services has been significant and at a scale that has had measurable impacts on poverty, the modest scale of outreach of the economic programmes ... is striking. While some 12 million people have been identified as broadly within the second economy, many programmes ... struggle to reach 50,000 people ... Many programmes are limited to a project level, without managing to unlock the significant power of government to impact at a wider societal level. (Philip \& Hassen, 2008:20)

This paper looks at how this generic challenge of achieving scale in our social and economic programmes manifests in the area of agriculture. Without delving into all the pressing issues that are of relevance to the small-scale farming sector (finance, marketing strategies, irrigation, etc.), it analyses the level of public resources available to support small-scale farmers, how these funds are spent, and who is reached, and on this basis proposes a set of options to be taken in the future to achieve scale and impact.

\section{Public expenditure to support small-scale farmers: Trends and incidence}

The amount of money spent by the government on the agricultural sector has grown impressively since the mid-1990s. Figure 1 illustrates this using three different measures. The first two, the top two lines in the graph, use data from the National Treasury's annual Budget Review, both inclusive and exclusive of land reform, to show the consolidated national and provincial expenditure on 'agriculture, forestry and fisheries'. The third measure, the lowest line in the graph, uses the provincial agriculture departments' expenditure. The difference between the consolidated expenditure series and the provincial agriculture expenditure series is because the former includes expenditure by the Department of Agriculture, Forestry and Fisheries (DAFF), and by the Agricultural Research Council and other national-level parastatals. 


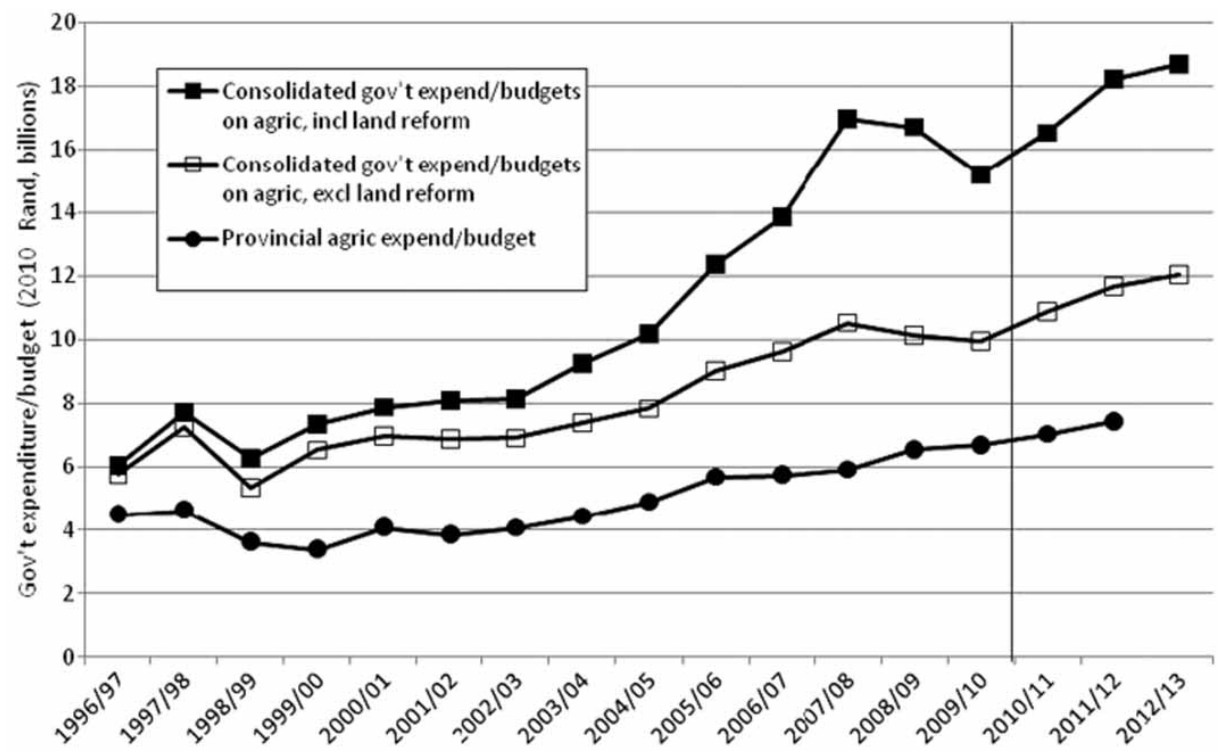

Figure 1: Agricultural sector expenditure/budget in constant 2010 rand, 1996/972012/13

Sources: Department of Finance (1999), National Treasury (2003, 2006, 2008, 2009, 2010), authors' own calculations.

To the left of the vertical line, the data points represent expenditure, while to the right they represent the medium-term budget estimates. The data have been adjusted for inflation (and for anticipated inflation) using the consumer price index. Thus, the upward trend is real - between 1996/97 and 2009/10, the annual consolidated expenditure on agriculture increased by about $150 \%$, and by $73 \%$ when land reform is excluded. Similarly, over this period the annual expenditure by the provincial agriculture departments increased by about $49 \%$. Notwithstanding the dip between $2007 / 08$ and 2009/10, and bearing in mind that the projected increase from 2010/11 to $2012 / 13$ may not happen, the increase is still significant. However, the share of the total government budget that went to agriculture in 2008/09 was only $2.3 \%$, far short of the African Union's Maputo Protocol benchmark of $10 \%$.

Although the increases are certainly significant, do these expenditure levels constitute 'a lot'? One way to put the figures in perspective is simply to divide them by the number of small-scale farmers. Given that there is little direct support to white commercial agriculture, the focus is on the number of black farming households, an estimate of which can be derived from Statistics South Africa's Labour Force Survey (LFS) (Stats SA, 2002, 2006, 2007) and from the General Household Survey (GHS) of 2009 (Stats SA, 2010). Using provincial agriculture expenditure, the estimated expenditure per 'agriculturally active black household' was over R2500 in $2009 / 10$, a real increase of $43 \%$ from the figure for 2001/02. Given that, as of 2009, there were almost 2.6 million black farming households, this is no small achievement. Moreover, given that the vast majority of black farming households practice subsistence farming, a per-household expenditure of a few thousand rand seems reasonable; it is considerably more than most such households spend on inputs in a typical year. 
However, what is known about the actual distribution of this expenditure among farmers? An answer to this question can be found by estimating from GHS 2009 apparently the first national survey to ask questions about different forms of agricultural support - the number of farmers deriving direct agricultural support. (Until 2007, the LFS asked questions about participation in agriculture, but not about support services. Stats SA's Rural Survey of 1997 is the only other large-scale survey that asked questions about agricultural support, but it was administered only in exBantustans, and enquired only about a very limited range of types of support.) Table 1 shows the numbers of agriculturally active black households receiving various forms of agricultural support in the 12 months before October 2009 (when the fieldwork for this study was done), and also the percentages that these constitute of the total number of agriculturally active black households. The bottom row shows the number of households that received any of the support services listed above, to arrive at a consolidated estimate of the number and share of black farming households that received at least some support. The two columns on the right show the numbers and percentages of households receiving support services, but focusing only on those households that were 'commercially oriented', which are defined here as those households that indicated that at least half of their agricultural production is sold rather than consumed by the household.

The overall impression created by the table is that access to agricultural support is extremely limited. Apart from access to livestock health services, the picture is quite sobering. Arguably of greatest concern is the extremely small share of agriculturally active households that received training or extension; however, here it must also be acknowledged that the wording of the GHS questionnaire was flawed, in that it asked

Table 1: Agriculturally active black households receiving agricultural support services

\begin{tabular}{|c|c|c|c|c|}
\hline & \multicolumn{2}{|c|}{$\begin{array}{l}\text { Agriculturally active } \\
\text { black households } \\
\text { receiving support in } \\
\text { previous year }\end{array}$} & \multicolumn{2}{|c|}{$\begin{array}{c}\text { Commercially oriented } \\
\text { agriculturally active black } \\
\text { households receiving } \\
\text { support in previous year }\end{array}$} \\
\hline & Number & Share $^{\mathrm{a}}$ & Number & Share $^{b}$ \\
\hline Training & 50806 & $1.9 \%$ & 18548 & $13.5 \%$ \\
\hline Visits from extension officers & 47077 & $1.8 \%$ & 14505 & $10.6 \%$ \\
\hline Grants & 5236 & $0.2 \%$ & 1284 & $0.9 \%$ \\
\hline Loans & 3822 & $0.1 \%$ & 1049 & $0.8 \%$ \\
\hline Inputs as part of a loan & 7752 & $0.3 \%$ & 3728 & $2.7 \%$ \\
\hline Inputs for free & 52377 & $2.0 \%$ & 9168 & $6.7 \%$ \\
\hline Livestock health services & 262568 & $10.0 \%$ & 29902 & $21.8 \%$ \\
\hline Other & 1773 & $0.1 \%$ & 278 & $0.2 \%$ \\
\hline Any one or more of the above & 339805 & $12.9 \%$ & 47676 & $34.8 \%$ \\
\hline
\end{tabular}

Source: Stats SA (2010).

Notes: The GHS for 2009 had a total sample of about 25300 black households. Of these, 5700 could be classified as 'agriculturally active' and 290 as 'commercially oriented'. Using the GHS weights, these two

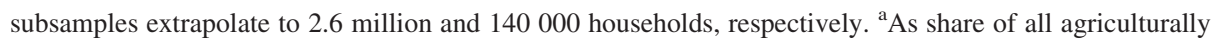
active black households. ${ }^{\mathrm{b}}$ As share of all commercially oriented agriculturally active black households. 
only about 'visits from extension officers', whereas in reality farmers' encounters with extension officers can occur in different places.

For commercially oriented black farming households, the situation is somewhat better, as one might have expected. However, it is still far from encouraging - only one third of these households received any form of direct agricultural support service in the 12month period ending October 2009.

The table obliges us to reconsider our interpretation of the expenditure. Although public expenditure on agriculture has risen significantly over the last decade and a half, and even though this expenditure appears to be ample relative to the number of agriculturally active households, in fact very few of these households are receiving direct support. The resources appear to be available, but only a small share of the households are benefiting from them. Why is this happening?

\section{Perspectives on the underperformance problem}

How can it be that such substantial sums of money are spent on supporting farmers, and yet the incidence of benefits is so slight? This section suggests some partial answers. Broadly, the argument that follows is that the government departments responsible for supporting farmers are making poor use of the resources at their disposal, do not have an adequate appreciation of their clientele, and prioritise avoiding underspending over having a broad impact.

\subsection{Lack of resources and/or money sinkholes?}

It is common cause that the agricultural support services are stretched. The inadequacy of the provinces' extension services is a central aspect of this more general problem. In recognition of the severity of the problem, in 2007/08 the National Department of Agriculture (NDA) initiated the Extension Recovery Plan (NDA, 2008). A former Minister of Agriculture and Land Affairs said it had been determined that there was 'understaffing by up to 5490 extension officers and a need to intensify training and visibility of our extension services' (Xingwana, 2008). Accordingly, extra resources of some R500 million were pledged over the three-year Medium-Term Expenditure Framework period.

While this is laudable and necessary, the first thing to recognise is that R500 million is a small amount of money compared with what is already spent on the salaries of provincial agriculture personnel. Split over three years, it represents only 5\% of the annual salary bill for provincial agriculture, and this does not take into account the fact that the money is not meant only or even mainly as a resource with which to hire more extension officers. Second, even if it was possible to hire another 5490 extension officers, this would require tripling the current size of the extension corps. Everything else being held equal, this would enable $5.4 \%$ of black farmers to receive attention as opposed to only $1.8 \%$. While this would represent a massive improvement, it would be a fairly insignificant one considering the scale of the need. As the Plan and subsequent statements indicate, it is a question not merely of the ratio of extension officers to farmers but also of choosing the right methodologies and tools. However, it is not clear that government is moving decisively in that direction. And third, when it comes to the provincial agriculture departments' collective annual salary bill of R3.3 billion, it is not even clear where this goes. This amount of money is vastly in excess of what is necessary to employ the country's extension officers (approximately 2000 to 2500 people). How can one reconcile these pieces of information? 


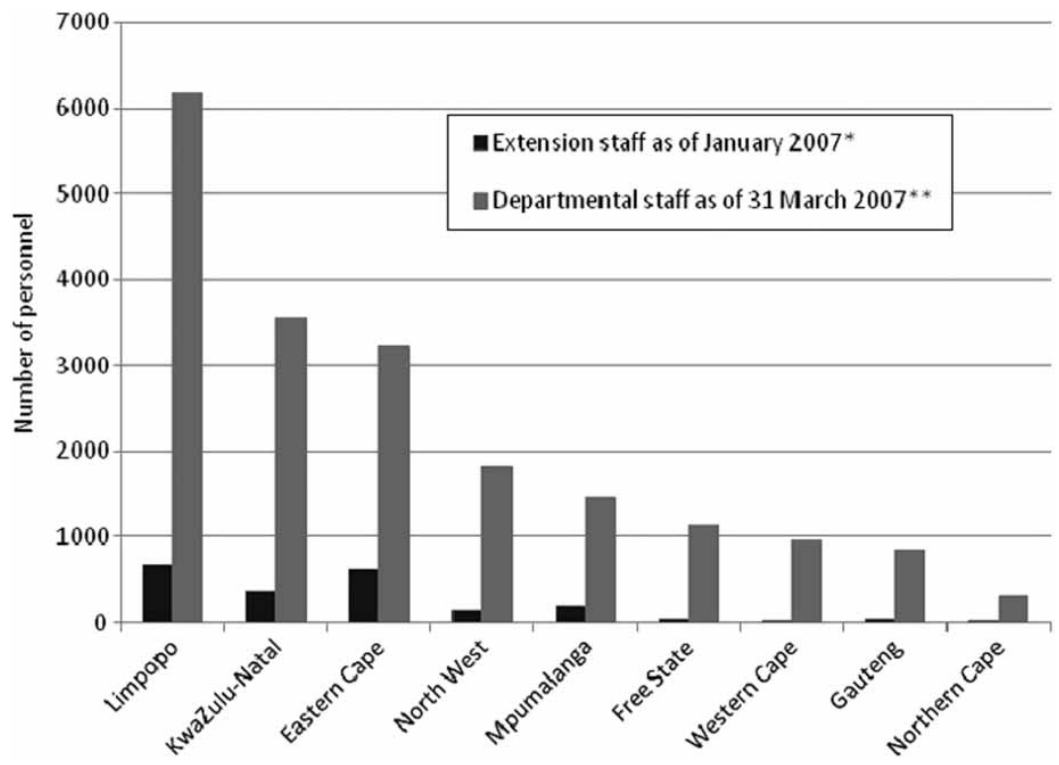

Figure 2: Extension staff and total staff complements, by province Sources: *NDA (2008). ${ }^{* *}$ National Treasury (2009).

One way to get to grips with this anomaly is to consider each province's number of 'genuine' extension officers relative to its total staff complement. Such a comparison is offered for 2007 in Figure 2. While this comparison is not meant to imply that there is no rationale for having non-extension personnel, given the supposed centrality of extension services to the functions of provincial agriculture departments, the picture that emerges is deeply worrying. One interpretation is that provincial agriculture departments have never fully succeeded in reducing the number of 'supernumeraries' (staff in excess of requirements) who were typically inherited from the apartheid-era homeland agriculture departments. Indeed, while in the mid-1990s the problem of supernumeraries was widely acknowledged, and there does appear to have been improvement (e.g. between 2002 and 2010 the collective personnel of the provincial agriculture departments declined by $26 \%$ ), at present little is being said publicly about the large remaining burden on provincial agriculture budgets. For example, the question of supernumeraries is mentioned in neither the agriculture department's Strategic Plan 2010/2011 (DAFF, 2010), nor any of the recent provincial agriculture budget votes, nor even the national Department of Agriculture's 2008 strategy for 'recovering' agricultural extension (NDA, 2008). In any event, while it is not possible to determine precisely what share of the non-extension personnel are in fact supernumeraries, the authors surmise that this share is large, and that the presence of large numbers of supernumeraries has enormous implications for the ability of provincial agriculture departments to perform their core functions.

\subsection{Most black farmers are invisible}

One reason why so few black farmers receive support appears to be that agricultural departments are unaware they exist. Ironically, this is well illustrated by reference to DAFF's recent attempt to make farmers more visible. In 2008, DAFF launched a pilot 
study for its Farmer Register Project. The overall objective of the initiative is to create a complete database of farmers, presumably to correct for the fact that Stats SA's agricultural censuses focus only on large-scale commercial farmers, most of whom are white. The DAFF report says that:

The main aim of the larger study, i.e. the Farmer Register, is to establish upto-date statistics of all agricultural producers in South Africa. The register will enable the Department of Agriculture, Forestry and Fisheries (DAFF) and other institutions to have accurate statistics of both existing commercial and emerging agricultural producers in the country. (2009:1, own emphasis)

The pilot study focused on Capricorn District Municipality, Limpopo. As per the proposed strategy for the 'larger study', extension officers played a key role in helping identify the farmers: 'Data collectors/enumerators were accompanied by extension officers to each farming unit' (DAFF, 2009:2). To be clear, the purpose of the pilot was not merely to test the questionnaire, but to test the efficacy of the methodology, through which a complete register of farmers is meant to be established. It is therefore significant that the total number of black farmers established by the pilot was 919, of whom 133 were 'commercial' and 786 'subsistence'. By contrast, according to the Labour Force Survey of March 2007 (Stats SA, 2007), there were about 293000 black individuals engaged in farming in Capricorn, of whom about 21000 were commercially oriented (i.e. they produced mainly for income-earning purposes). While the LFS data are not particularly reliable at district level - for example, according to the March 2006 LFS there were 'only' 254000 black individuals engaged in farming in Capricorn - they provide a reasonable order-of-magnitude estimate. The difference between a figure of 919 and 293000 is almost unbelievable. If DAFF was concerned about the efficacy of its methodology, it gave no hint of this in its report.

The point is not to criticise the Register initiative, whose intentions are worthwhile and whose shortcomings are understandable. (Perhaps it is no coincidence that the ratio of 919 to 293000 is very roughly the same as the share of agriculturally active black households in Limpopo that, according to the GHS 2009, had had contact with an extension officer in the previous year.) Rather, the point is that our agricultural support services do not appear to be attuned to the reality around them, perhaps because their inadequate capacity hinders them.

\subsection{A preference for quality over quantity, or an attempt to reduce underspending?}

In February 2008 the then national Department of Agriculture (NDA) briefed the agricultural portfolio committee regarding the Comprehensive Agricultural Support Programme (CASP). CASP originated from the 2003 intergovernmental fiscal review of agriculture - conducted by the National Treasury together with the Minister and MECs $^{1}$ - which found that agriculture was under-funded, and in particular suffered from a gap in capital funding. CASP was launched in 2004. While it was not the largest form of agricultural support, it quickly became the most significant capital budget line potentially available to small-scale black farmers.

\footnotetext{
${ }^{1}$ Members of the (provincial) executive council, i.e. provincial ministers.
} 
In the course of his presentation, the NDA official noted that, despite its budget growing significantly over the previous few years, CASP continued to benefit more or less the same number of people. He explained thus:

The budget of CASP has been growing. What that means is that when CASP started in 2004/05, we had a lot of small projects, but today the budget has almost doubled and the number of beneficiaries and the number of projects have not changed. That means we are getting deeper in terms of how we support the projects, but again projects have become larger, and the quality of our investment has improved over the years. (PMG, 2008)

While it stands to reason that concentrating resources on smaller numbers of beneficiaries and projects is a means of improving the 'quality' of those particular projects, it is obviously at the expense of reaching larger numbers of farmers. (Recall Table 1 above, which shows that the share of agriculturally active black households that reported receiving agricultural 'grants' in the previous year was about $0.2 \%$.) Moreover, there is evidence to suggest that improving project quality was not necessarily the main rationale for the trend towards a few large projects rather than many small ones. According to one provincial official responsible for the implementation of CASP, a primary consideration was to reduce underspending:

There's no cap on individuals - they can get anything from R20 000 up to R9 million - there are no guidelines. We got a lot of flak for that. We have had about 120 to 130 projects in the Eastern Cape, so the policy being pushed from national is to cut down projects, maybe to just six for the province, or one per municipality, in order to speed up administration. To administer R10 is as much as to administer R10 million, so we are meant to do fewer, bigger projects. The more projects you have, the more work you have. (Provincial Department of Agriculture manager interview, 2009, quoted in Hall \& Aliber, 2010:16)

Similar tensions are observable in other developmental endeavours, such as land redistribution and lending to support small-scale enterprise. The trend in land redistribution over the period 1995 to 2008 was to make far larger, far fewer grants for land acquisition (Aliber \& Hall, 2010). The bureaucratic impetus to reduce underspending is understandable - unspent government resources represent benefits that are not being enjoyed by people on the ground. Underspending also means that future budgets are likely to be cut in line with what was actually spent in previous years. The irony, however, is that as programmes are modified to reduce underspending, the ultimate consequence is that even fewer people benefit than before. Moreover, there is little evidence to suggest that more spending on a project means a better project.

\section{Lessons from the past}

There have been various programmatic attempts in the distant and recent past to support small-scale farmers. In this section we briefly describe two: the Farmer Support Programmes, which from the late 1980s attempted to provide holistic support to farmers in the various homelands, and the Massive Food Production Programme, initiated in the Eastern Cape in 2003 in an attempt to dramatically increase land use and agricultural production there. ${ }^{2}$

${ }^{2}$ This section is largely adapted from Aliber \& Hall (2010:16-17). 


\subsection{The Farmer Support Programmes}

In the mid-1980s, the Development Bank of Southern Africa (DBSA) introduced its Farmer Support Programmes (FSPs). At the time, the approach was novel in the South African context, in that it focused on supporting smallholders in the homeland areas, as opposed to the more costly and poorly performing large capital-intensive homeland schemes such as the state-run and parastatal-run farms. The DBSA defined a farmer as anyone who used resources part-time or full-time to produce agricultural goods. The overall development objective of the FSPs was 'promotion of structural change away from subsistent agricultural production to commercial production by providing comprehensive agricultural support services and incentives to existing farmers' (Van Rooyen, 1995:6).

After a mid-term evaluation this objective was redefined in 1989 to focus on providing farmer access to support services over a wide base. The FSPs ran between 1987 and 1993, focusing on the supply of inputs and capital to farmers, mechanisation services, marketing services, training and extension, and research. The DBSA estimated that the project reached 25000 smallholders through 35 FSPs before it was overtaken by the demise of the homelands and their reintegration into the nine provinces which emerged from the new democratic dispensation in 1994.

Hayward \& Botha (1995) identified a range of problems associated with the extension, training and research services provided as part of the FSPs, such as poor training of extension staff, lack of inter-agency coordination, excessive use of purchased inputs and consequent indebtedness. Most of the problems appear to have been the typical shortcomings associated with rendering support to smallholders, and in fact many are still very much part of the domestic landscape. A critique from a different perspective was offered by Sender, who argued that 'even if the programme was extended to a level which is almost certainly not fiscally sustainable, you would only be reaching a tiny proportion of either the rural population or those who see their future in farming' (1995:254).

Partly on the basis of Sender's critique, the FSPs earned the reputation of being extravagantly expensive. Based on figures presented by Van Rooyen, the cost per farmer was about R25 000 over a five or six year period, expressed in 2008 rand (Van Rooyen, 1995). Compared to schemes such as CASP, this seems exceedingly modest. However, it is approximately twice what is currently spent (on average) on each black farming household by the provincial agriculture departments, and is thus clearly unaffordable on a national scale.

Although the FSPs recognised that black farmers encountered a range of obstacles to improved production and market access (Van Rooyen, 1995), they aimed to improve production without substantially altering the institutional and market context in which this production occurred. Participants in the FSPs competed for market access with their white counterparts who, because of substantial subsidisation, were able to undercut them (Fischer \& Vink, 1995). It has also been argued that the FSPs were characterised by a top-down process of development planning, in practice sacrificed their purported commitment to gender equality, and failed to explore options for highvalue crops and post-harvest value-adding (Cooper, 1995). They did not target the poorest households or women, but also did not target those households with the resources to expand production, and so fell between two stools - achieving objectives neither of improved welfare nor increased output (Sender, 1995). 


\subsection{Siyakhula/Massive Food Production Programme}

The Siyakhula (Xhosa - 'We grow')/ Massive Food Production Programme (MFPP) was launched in the Eastern Cape in 2003 with the aim of promoting successful black commercial farmers in the province's ex-Bantustan areas. This Programme operates by providing state funds for grants and loans to participants and scaling the grants down over a four-year period, as follows: $100 \%$ in Year One; $75 \%$ in Year Two; 50\% in Year Three; and to 25\% in Year Four (ECPG, 2008). Despite widespread interest, delays in disbursing funds led to low uptake, and in subsequent years high debt levels contributed to farmers choosing to exit or be excluded. The Programme was successful in bringing about significant improvements in yields - from an average of 1 to 3.75 tonnes per hectare - but from a diminishing core of farmers shouldering rising levels of debt and risk that proved to be unsustainable in many instances (GRAIN, 2008; Tregurtha, 2008). A key lesson has been the need to replicate and scale up its 'value-chain' approach to restructuring, by intervening in up- and downstream industries, which in principle could support the development of local service and input supply industries (Nilsson \& Karlsson, 2008). Apart from the problem of excessive debt (which is reminiscent of the FSPs), a major concern expressed about the MFPP was the requirement that smallholders form themselves into groups for the sake of creating larger, contiguous blocks of fields. This has been acknowledged by the Eastern Cape's Department of Agriculture and Rural Development in its most recent strategic plan: 'Massive Food Programme needs a change of approach i.e. a shift from group farming towards individual farming with strong support for farmers to become commercial farmers' (ECDARD, 2010:49).

One interesting feature of both the MFPP and the FSPs is that they began with ambitious aims, but were hampered by inadequate capacity on the ground and so never reached the scale intended. The Eastern Cape Department has recently undertaken to increase the number of extension officers by a factor of more than three over the next four or five years (ECDARD, 2010:22). Another notable feature is that both interventions sought to reinvent themselves after a short while as experience accumulated and evaluations identified shortcomings in design. Arguably the most important shifts in this respect were in determining who the target clientele were and the vision that the interventions had for the target group. Together with inadequate impact, clarifying the vision and setting priorities remains the big open challenge in the government's efforts to support small-scale agriculture.

\section{Conclusion: Options and priorities for the future}

In view of South Africa's massive unemployment problem, government has determined that the underlying purpose of having a small-scale farmer emphasis is to maximise the creation of livelihoods. The drive must be to identify the sector's potential to contribute to labour absorption and poverty reduction, particularly in the economically depressed areas of the ex-Bantustans, where (self-)employment opportunities are desperately needed, and then help it to fulfil this potential.

The analysis above identifies some of the obstacles to such a programme. In view of these challenges, what should the strategy look like?

An important element of such a strategy is to accept that the expansion of the small-scale farmer sector should build on the very large subsistence sector; in other words, it should promote the 'graduation' of subsistence producers so that they can earn an income as 
commercial smallholders. In effect, this is what the FSPs sought to do. But beyond this, what and how?

One way to answer this question is to look at how to build on existing production and to support the sectors in which small-scale farmers are already involved. In many parts of the country this would mean livestock production (cattle and poultry, as well as sheep, goats and pigs). The basic limitation of such a strategy is its path dependence - the assumption that the spheres of production in which small farmers are engaged are optimal, and that the barriers to entry into other sectors are prohibitive, or that there is some intrinsic economic reason why small farmers cannot branch into new areas of production. Many such assumptions are spurious. International experience shows that crops mostly grown by commercial or large estate farming can be adapted successfully by small farmers, given the right institutional and policy environment. Tea and coffee in Kenya and cotton in Zimbabwe are among the examples of this 'transition' of products from the large-farm to the small-farm sector, bringing benefits to small farmers. (However, why small-scale sugarcane production in Mpumalanga and KwaZulu-Natal appears to have stagnated is a puzzle that requires cautious and careful consideration.)

A second approach is to explore sectors in which small-scale farmers could hypothetically succeed, given considerations of farming systems, input and production costs, and agro-ecology. It has been widely noted that communal areas that are home to many of the country's small-scale farmers are in regions with relatively high rainfall, yet the potential for cultivation has not been tapped. Nor has the potential for small farmers to supply fresh produce to local or nearby urban markets been realised.

Both of the above approaches have merit. However, the authors propose a third alternative. Instead of policy makers 'picking winners' by focusing support for smallscale farmers on specific sectors, a small-scale farming strategy could provide generic support and infrastructure in the regions where these farmers are concentrated. Smallscale farmers are overwhelmingly concentrated in just a few districts (e.g. taken together, Vhembe district in Limpopo, OR Tambo in the Eastern Cape, Ugu in KwaZulu-Natal and Ehlanzeni in Mpumalanga account for about 26\% of all black small-scale farmers in the country; Aliber \& Hall, 2010). A geographically targeted strategy may provide greater options for farmers to adapt and diversify their production, by creating generalised conditions for success.

The most fundamental political choice that must be made, though, is about the future agrarian structure. Scenarios for the future of the rural areas, and agriculture's future contribution to the rural economy and to providing good quality livelihoods, can inform policy decisions by clarifying the choices and quantifying trade-offs. A scenario exercise undertaken by the Human Sciences Research Council, in partnership with the University of Pretoria, illustrates the choices to be made about what kind of agricultural growth path to pursue and, projecting the growth or decline of agricultural employment or self-employment in these different sectors by 2020, shows alternative trajectories for farming (Aliber et al., 2008). Two of the least appealing scenarios are the 'continuation of current trends' in redistributive land reform and the 'continued stagnation of former homeland agriculture'. The loss of livelihoods predicted for these sectors makes the continuation of existing policy approaches very unattractive. However, a number of more hopeful scenarios are presented. These suggest that substantial numbers of livelihoods can be created through a mixed strategy focused 
primarily on small-scale farming - both semi-subsistence and semi-commercial alongside a smaller programme capable of supporting growing numbers of black commercial farmers.

The 2008 World Development Report emphasises the central place of agriculture in development and the importance of smallholder-led agricultural development (World Bank, 2007). It makes a powerful case for major investments in agriculture, including by governments and international development institutions, demonstrating the effectiveness of smallholder agriculture as a route to rural poverty alleviation by showing that an increase in agricultural labour productivity is three times more likely to raise the incomes of the poorest than non-agricultural productivity increases (World Bank, 2007:39). The World Development Report's rationale for prioritising a smallholder-led path of agricultural development is that this is the most effective way to promote both equity and efficiency in the sector. Building on its view of an 'inverse size-productivity relationship' - that, other things being equal, small farms are more productive than large farms - it sets out the argument as follows:

Smallholder farming - also known as family farming, a small-scale farm operated by a household with limited hired labor - remains the most common form of organization in agriculture, even in industrial countries. The record on the superiority of smallholder farming as a form of organization is striking. Many countries tried to promote large-scale farming, believing that smallholder farming is inefficient, backward, and resistant to change. The results were unimpressive and sometimes disastrous. State-led efforts to intensify agricultural production in subSaharan Africa, particularly in the colonial period, focused on large-scale farming, but they were not sustainable. In contrast, Asian countries that eventually decided to promote small family farms were able to launch the green revolution. They started supporting smallholder farming after collective farms failed to deliver adequate incentives to produce, as in China's farm collectivization, or on the verge of a hunger crisis, as in India and Indonesia. Countries that promoted smallholder agriculture - for various political reasons - used agriculture as an engine of growth and the basis of their industrialization. (World Bank, 2007:91)

Yet other things are seldom if ever equal (see Sender \& Johnston, 2004, among others). Small farmers face disadvantages in access to credit, input supply, transport and storage, and in output markets. So while small farms can be efficient in terms of factor productivity, they may face constraints which prevent small farmers from investing in and profiting from production. The challenge is therefore not merely to 'integrate' small farmers into these value chains.

A strategy to support small-scale farmers must be linked to industrial strategy, in so far as downstream industry procurement and marketing practices are hostile to small farmers. It also requires that commodity organisations support small-scale farmers. Getting the institutional context right for small farmers requires overcoming institutional obstacles that impose high transaction costs. Both public intervention to support service provision to small-scale farmers and collective action by small-scale farmers themselves are needed. Poulton et al. (2005) show the importance of a public sector role in lowering coordination costs for small farmers through seed funds for producer associations, and support to service suppliers to provide goods and services and to traders to provide a ready market for small surpluses. Their research shows that 
potential service suppliers face uncertain demand for their services and that such assurance is lacking in poor rural areas that have not yet achieved a widespread transition out of low input/ low output farming unless some external agent undertakes to provide the important missing services or coordinates provision of the missing services by other actors' (Poulton et al., 2005).

State support or subsidisation of service providers - such as tractor services - can enable smallholder farmers to overcome these obstacles related to scale, as well as coordination problems, and to act collectively to overcome high transaction costs.

A core choice then is whether to support many small-scale farmers to keep doing what they are already doing and produce a larger share of their household food requirements (i.e. 'food security' or 'production without accumulation'); to enable a smaller number of small-scale farmers to become fully commercial farmers and raise their output and incomes (i.e. 'ladders-up' or 'accumulation for the few'); or to support many smallscale farmers to keep doing what they are already doing, but to increase their productivity, scale up, diversify their products, and raise their incomes (i.e. 'accumulation from below').

The weight of the research evidence reviewed above shows that, while these three strategies can co-exist, most past and existing policy initiatives have focused only on the first two - 'food security' for many poor households and 'ladders-up' for a few better-off farmers. The emphasis of a new national initiative to support small-scale farmers should be on achieving scale and impact, enabling 'accumulation from below' for a substantial portion of the existing population of small-scale farmers. Between the agendas of welfare and food security for the poor on the one hand, and narrow empowerment and commercialisation on the other, this must make possible an alternative path of widespread sustainable growth and improvement in the small-scale farming sector, and the creation of an emerging 'missing middle' of successful small farmers.

\section{References}

Aliber, M \& Hall, R, 2010. Development of evidence-based policy around small-scale farming. Report commissioned by the Programme to Support Pro-Poor Policy Development, Pretoria, on behalf of the Presidency.

Aliber, M, Baipheti, M \& Jacobs, P, 2008. Agricultural employment scenarios. In Hall, R (Ed.), Another Countryside? Policy Options for Land and Agrarian Reform in South Africa. Institute for Poverty, Land and Agrarian Studies (PLAAS) School of Government, University of the Western Cape, Cape Town.

Cooper, D, 1995. Shifting the perspective. In Singini, R \& Van Rooyen, J (Eds), Serving Small Scale Farmers: An Evaluation of the DBSA's Farmer Support Programmes. Development Bank of Southern Africa, Halfway House.

DAFF (Department of Agriculture, Forestry and Fisheries), 2009. Farmer Register Pilot Study: Statistical Report. DAFF, Pretoria.

DAFF (Department of Agriculture, Forestry and Fisheries), 2010. Strategic Plan for the Department of Agriculture, Forestry and Fisheries 2010/2011. DAFF, Pretoria.

Department of Finance, 1999. Budget Review 1999. Department of Finance, Pretoria.

ECDARD (Eastern Cape Department of Agriculture and Rural Development), 2010. Strategic Plan 2010/11-2014/15. Province Government of the Eastern Cape, Bisho.

ECPG (Eastern Cape Provincial Government), 2008. Assessment of Provincial Agrarian Transformation, Land Reform and Food Security Programmes (Provincial Growth and 
Development Plan). Office of the Premier, Eastern Cape. Prepared by Kubukeli Consulting Agency, East London.

EDD (Economic Development Department), 2010. The New Growth Path: The Framework. Economic Development Department, Pretoria.

Fischer, A \& Vink, N, 1995. Sheds, schools, and service centres: The Farmer Support Programme in KaNgwane, Lebowa and Venda. In Singini, R \& Van Rooyen, J (Eds), Serving Small Scale Farmers: An Evaluation of the DBSA's Farmer Support Programmes. Development Bank of Southern Africa, Halfway House.

GRAIN (Genetic Resources Action International), 2008. Lessons from a green revolution in Africa. Seedling October, 22-9.

Hall, R \& Aliber, M, 2010. The case for re-strategising spending priorities to support small scale farmers in South Africa. Working Paper No. 17, Institute for Poverty, Land and Agrarian Studies (PLAAS), University of the Western Cape, Cape Town.

Hayward, J \& Botha, C, 1995. Extension, training and research. In Singini, R \& Van Rooyen, J (Eds), Serving Small Scale Farmers: An Evaluation of the DBSA's Farmer Support Programmes. Development Bank of Southern Africa, Halfway House.

National Treasury, 2003. Budget Review 2003. Government Printer, Pretoria.

National Treasury, 2006. Budget Review 2006. Government Printer, Pretoria.

National Treasury, 2008. Budget Review 2008. Government Printer, Pretoria.

National Treasury, 2009. Provincial Budgets and Expenditure Review: 2005/06-2011/12. Government Printer, Pretoria.

National Treasury, 2010. Budget Review 2010. Government Printer, Pretoria.

NDA (National Department of Agriculture), 2001. Strategic Plan for South African Agriculture. NDA, Pretoria.

NDA (National Department of Agriculture), 2008. The State of Extension and Advisory Service within the Agricultural Public Service: A Need for Recovery. Government memorandum. NDA, Pretoria.

Nilsson, A \& Karlsson, H, 2008. 'The Baby of the Government': A Case Study of the Implementation of the Massive Food Production Programme and Genetically Modified Maize into Smallholder Farming in Rural South Africa. Swedish University of Agricultural Sciences, Uppsala.

Philip, K \& Hassen, E-K, 2008. The review of second economy programmes: An overview for the Presidency's fifteen-year review. Second Economy Strategy Project, Trade \& Industrial Policy Strategies (TIPS), Pretoria.

PMG (Parliamentary Monitoring Group), 2008. Proceedings of Parliamentary Portfolio Committee for Agriculture, Forestry and Fisheries, 20 February. Audio file. www.pmg.org.za/report/ 20080220-comprehensive-agriculture-support-mafisa-funding-programmes-agriculturedepartment-b Accessed 16 August 2010.

Poulton, C, Dorward, A \& Kydd, J, 2005. The future of small farms: New directions for services, institutions and intermediation. World Development 38(10), 1413-28.

Sender, J, 1995. A failure of analytical categorisation. In Singini, R \& Van Rooyen, J (Eds), Serving Small Scale Farmers: An Evaluation of the DBSA's Farmer Support Programmes. Development Bank of Southern Africa, Halfway House.

Sender, J \& Johnston, D, 2004. Searching for a weapon of mass production in rural Africa: Unconvincing arguments for land reform. Journal of Agrarian Change 4(1-2), 142-64.

Stats SA (Statistics South Africa), 2002. Labour Force Survey February 2002. Stats SA dataset, CD ROM. Statistics South Africa, Pretoria.

Stats SA (Statistics South Africa), 2006. Labour Force Survey March 2006. Stats SA dataset, CD ROM. Statistics South Africa, Pretoria.

Stats SA (Statistics South Africa), 2007. Labour Force Survey March 2007. Stats SA dataset, CD ROM. Statistics South Africa, Pretoria.

Stats SA (Statistics South Africa), 2010. General Household Survey 2009. Stats SA dataset, CD ROM. Statistics South Africa, Pretoria. 
The Presidency, 2010. Delivery agreement: Outcome 7. www.thepresidency.gov.za Accessed 14 January 2011.

Tregurtha, N, 2008. The Eastern Cape Siyakhula Massive Crop Production Programme. PowerPoint presentation, Second Economy Project, Trade \& Industrial Policy Strategies (TIPS), 30 September, Centurion, South Africa.

Van Rooyen, J, 1995. Overview of DBSA's Farmer Support Programme: 1987-1993. In Singini, R \& Van Rooyen, J (Eds), Serving Small Scale Farmers: An Evaluation of the DBSA's Farmer Support Programmes. Development Bank of Southern Africa, Halfway House.

World Bank, 2007. Agriculture for Development: World Development Report 2008. World Bank, Washington, DC.

Xingwana, L, 2008. Speech on the Debate on Budget Vote Nos 23 - Agriculture and 27 - Land Affairs. Unrevised Hansard of the proceedings of Extended Public Committee, Committee Room E249, 21 May. www.pmg.org.za/node/14469 Accessed 20 November 2010. 